\title{
Asilidae (Diptera) of two Atlantic Forest protected areas of Rio de Janeiro, Southeastern Brazil
}

\author{
DANILO P. MOREIRA-JUNIOR and VALÉRIA C. MAIA
}

Museu Nacional, Departamento de Entomologia, Quinta da Boa Vista, s/n, São Cristóvão, 20940-040 Rio de Janeiro, RJ, Brazil

Manuscript received on October 3, 2017; accepted for publication on December 8, 2017

\begin{abstract}
As few Asilidae inventories of Rio de Janeiro areas have been published, there are many data gaps. This paper aims to contribute to the knowledge of richness, abundance and distribution of this family in this State. From January 2013 to March 2014, insects were collected monthly using Malaise traps and every two months using entomological nets in the Reserva Biológica União (REBIO), and Estação Ecológica Estadual de Guaxindiba (EEEG). 682 specimens of Asilidae were collected in the present study, distributed in 31 genera and 51 species (20 identified and 31 unidentified), 527 of REBIO (in 19 genera and 38 species - 14 identified and 24 unidentified), and 155 specimens of EEEG (in 12 genera and 19 species - 6 identified and 13 unidentified). Leptogaster was the most abundant genus being L. tropica (Curran 1934) the most abundant species in the REBIO, with 268 specimens and Leptogaster sp., with 54 specimens, the most abundant in the EEEG. All records of genera and species in the present study are new in the REBIO and EEEG, wich contribute to the knowledge of the Asilidae geographic distribution and richness in the State of Rio de Janeiro.
\end{abstract}

Key words: Abundance, distribution, richness, tableland forest, dense ombrophilous forest.

\section{INTRODUCTION}

Among the Diptera, Asilidae (commonly known as robber flies) are easily recognized by the deep vertex between the eyes, hairy face, perforated and heavily developed hypopharynx, robust thorax and strong legs. They are very abundant and diverse, with a great variety of species, which can be attributed to its cosmopolitan distribution (Hull 1962). The family includes 7,531 species in about 556 genera. In the Neotropical Region, there are 1,485 species distributed in 217 genera (Pape et al.

Correspondence to: Danilo Pinto Moreira-Junior

E-mail: danilo.dj@gmail.com
2009, Artigas and Vieira 2014, Vieira and Rafael 2014).

Asilidae are known for their predatory habits in the larval and adult stages. They have a voracious appetite for other arthropods, helping to maintain the ecological balance of habitats as they feed on bees, wasps, dragonflies, crickets, other flies and even some spiders (Joern and Rudd 1982, Shurovnekov 1962). The activity of predation and predatory choice of adults is well documented.

Few Asilidae inventories have been published in Brazil. Guimarães et al. 2016 provided the most recent records in the State of Rio de Janeiro (in the 


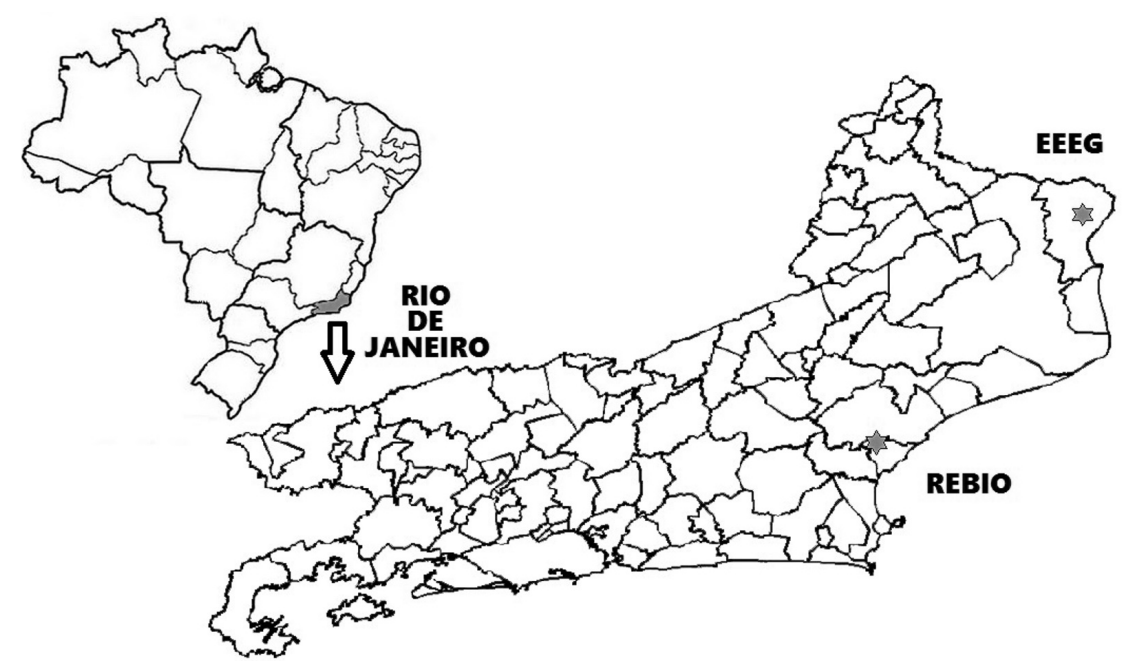

Figure 1 - Map of Brazil, showing the location of state of Rio de Janeiro, and map of state of Rio de Janeiro with the location of the Reserva Biológica União (REBIO) and the Estação Ecológica Estadual de Guaxindiba (EEEG).

municipality of Mangaratiba), where six species of robber flies were registered.

The state of Rio de Janeiro is occupied by only one biome, Atlantic Forest. With a high index of endemism and several vegetal physiognomies (Morellato and Haddad 2000), this biome is strongly threatened by human action (Carvalho et al. 2010), being considered as one of the biodiversity hot spots in the world.

The present study aims to increase the knowledge about Asilidae fauna in the Atlantic Forest of the State of Rio de Janeiro. It is part of the Biota Diptera Fluminense project, whose main proposal was to inventory the diversity of Diptera in this State. This project indicated little or not yet investigated areas in relation to Dipterofauna and, based on these geographic gaps, two collecting sites were established: Reserva Biológica União (REBIO) and Estação Ecológica Estadual de Guaxindiba (EEEG).

\section{MATERIALS AND METHODS}

\section{STUDY SITE}

REBIO and EEEG are situated in the state of Rio de Janeiro, Southeastern Brazil (Fig. 1). The REBIO, with about three thousands hectares, is located in the mesoregion of the coastal valleys, in the north of the state, at coordinates S $22^{\circ} 25^{\prime} 35^{\prime \prime}$ and $\mathrm{W} 42^{\circ}$ $02^{\prime} 04$ ". "It maintains primary elements of flora and fauna and has the greatest wealth and plant diversity among all the remnants of the Atlantic Forest in the state of Rio de Janeiro" (Moreira-Junior and Maia 2016).

This reserve covers the cities of Macaé (1\%), Casimiro de Abreu (46\%) and Rio das Ostras (53\%), and preserves a rich fauna, including endemic and endangered species such as the ocelot (Leopardus pardalis, Linnaeus 1758), the puma (Felis concolor, Linnaeus 1771), and the maned sloth (Bradypus torquatus, Desmarest 1816), besides being known to shelter one of the largest wild populations of the golden lion tamarin (Leontopithecus Rosalia, Linnaeus 1766). In the REBIO (Fig. 2), the following ecosystems are found: dense ombrophylous forest, submontane ombrophylous forest and dense lowland ombrophylous forest (MMA 2016).

The EEEG (Fig. 3), with 3,260 hectares, is situated in the city of São Francisco de Itabapoana, at coordinates S $21^{\circ} 24^{\prime} 28^{\prime \prime}$ and W $41^{\circ} 05^{\prime} 33^{\prime \prime}$. It is characterized as an area of semideciduous 


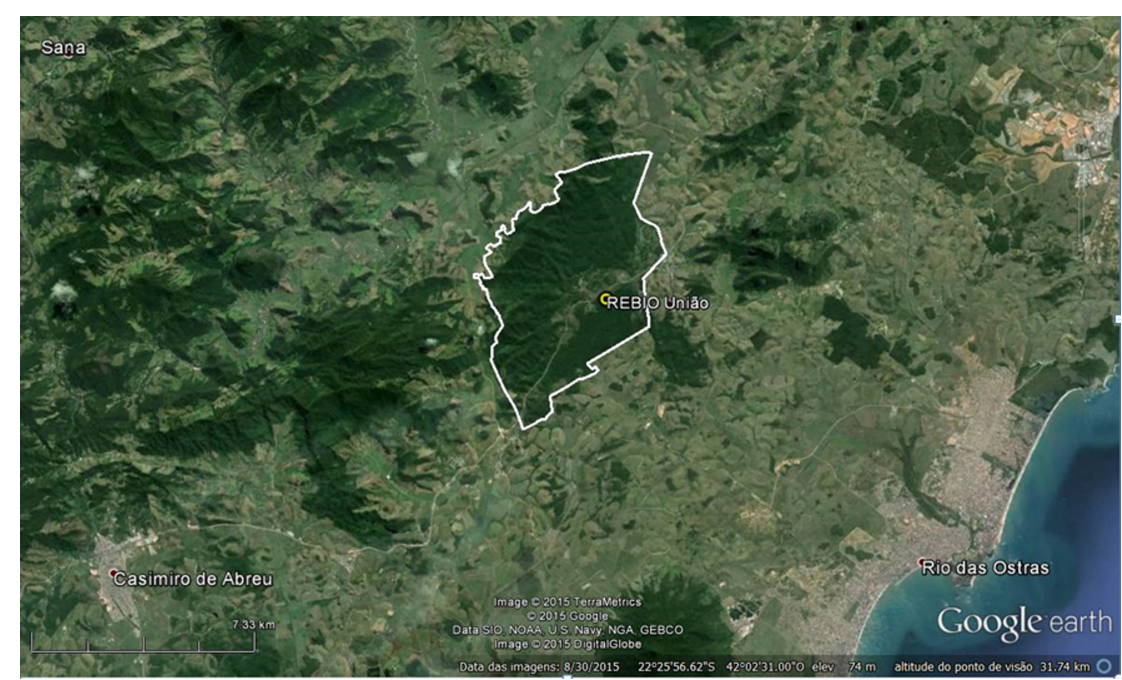

Figure 2 - Map indicating the location of the Reserva Biológica União (REBIO), state of Rio de Janeiro.

seasonal lowland forest, being the most significant and important vegetation cover of the Northeast of the state of Rio de Janeiro. It is the largest and last remnant of flat topography and of great extension, receiving the denomination of forest on tertiary board, being found in a plain (INEA 2000).

\section{COLLECTIONS}

During the period between January, 2013 to March, 2014 collections were made with Malaise traps placed on the first expedition and maintained throughout the period, and their content was collected each month. Bimonthly active collections with entomological network were also made, during three days of each expedition, in both study sites.

At REBIO, three tracks were investigated: Buracão (S $22^{\circ} 25^{\prime} 43.8^{\prime \prime}$ - S $22^{\circ} 25^{\prime} 45.6^{\prime \prime}, \mathrm{W} 42^{\circ}$ $\left.02^{\prime} 19.5^{\prime \prime}-\mathrm{W} 42^{\circ} 02^{\prime} 24.7^{\prime \prime}\right)$, Interpretativa (S $22^{\circ}$ $25^{\prime} 310^{\prime \prime}$ - S $22^{\circ} 25^{\prime} 397^{\prime \prime}, \mathrm{W} 42^{\circ} 02^{\prime} 159^{\prime \prime}-\mathrm{W} 042^{\circ}$ $\left.02^{\prime} 366^{\prime \prime}\right)$ and Três Pontes (S $22^{\circ} 25^{\prime} 160^{\prime \prime}-\mathrm{S} 22^{\circ}$ 25' 380", W $42^{\circ} 01^{\prime} 532^{\prime \prime}$ - W $\left.42^{\circ} 02^{\prime} 229^{\prime \prime}\right)$, where Malaise traps were placed, one per track except for the last one, where two traps were placed: one near the railway line and the other about three kilometers from the beginning of the trail, near a lake.

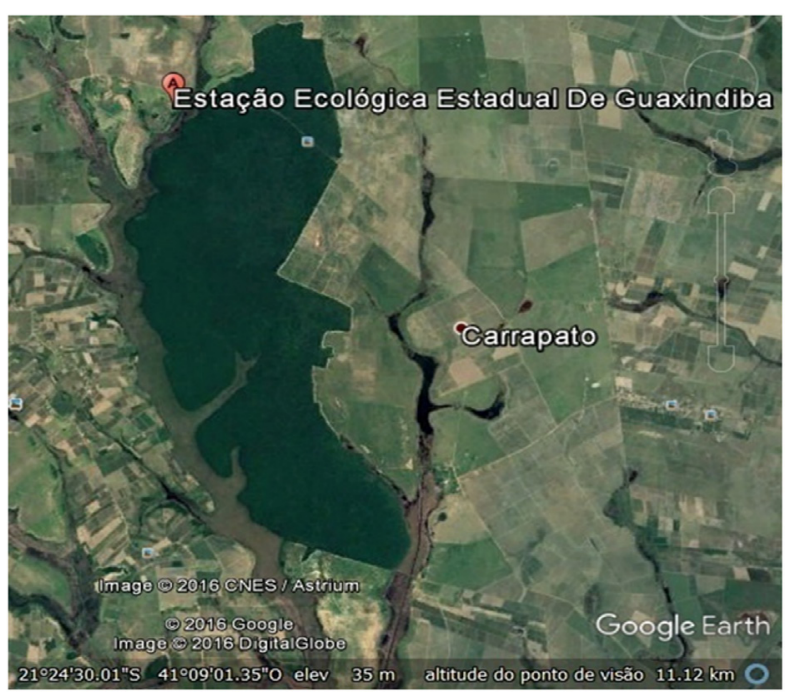

Figure 3 - Map indicating the location of the Estação Ecológica Estadual de Guaxindiba (EEEG), state of Rio de Janeiro.

At the EEEG, three tracks were investigated:

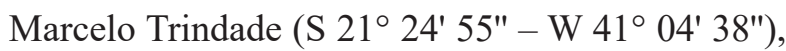

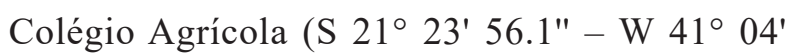
$\left.44.0^{\prime \prime}\right)$, Vera (S $\left.21^{\circ} 24^{\prime} 26^{\prime \prime}-\mathrm{W} 41^{\circ} 04^{\prime} 59^{\prime \prime}\right)$, and Abelha (S $\left.21^{\circ} 24^{\prime} 40.7^{\prime \prime}-\mathrm{W} 41^{\circ} 04^{\prime} 53.7^{\prime \prime}\right)$ as well as the surrounding area of the Charco (S 21 $1^{\circ} 24^{\prime}$ $\left.59.7^{\prime \prime}-\mathrm{W} 41^{\circ} 04^{\prime} 35.5^{\prime \prime}\right)$, where Malaise traps were placed, one per track.

All the collected material was transported to the Diptera laboratory of the Museu Nacional/ 


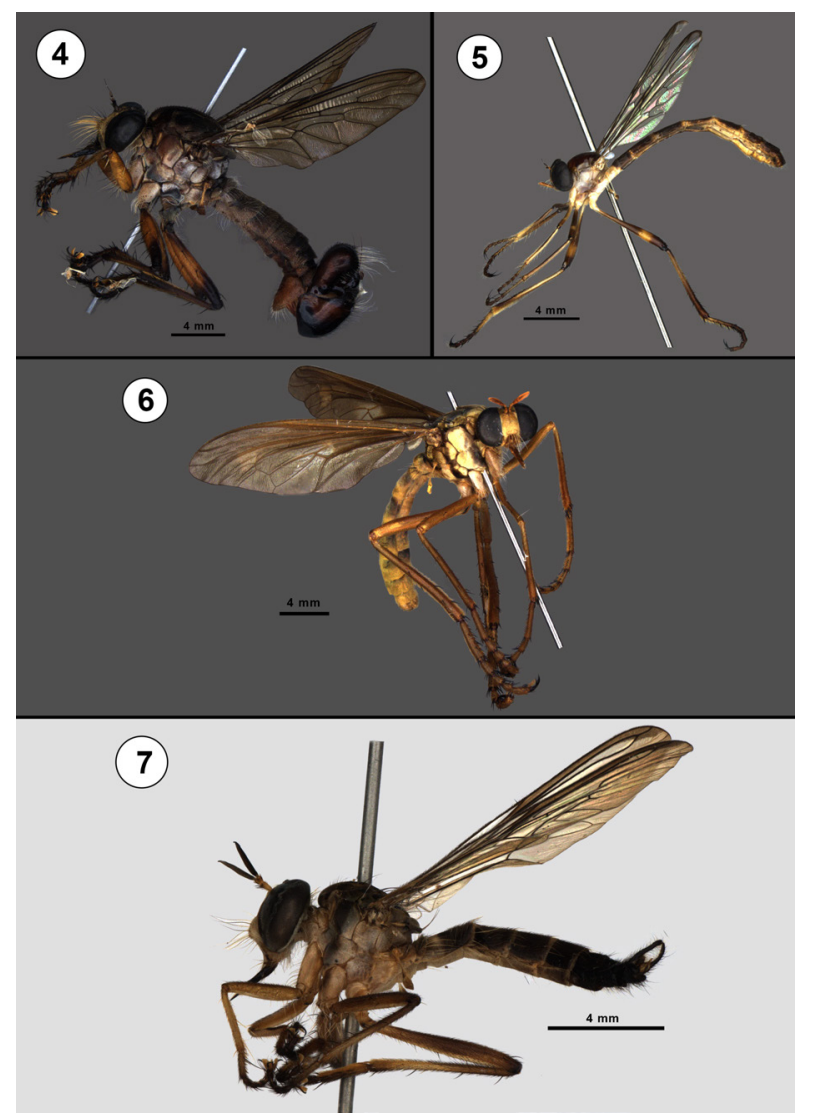

Figures 4-7 - Asilidae: 4. Lecania leucopyga; 5. Leptogaster tropica; 6. Blepharepium cajannense coarctatum; 7. Glaphyropyga pollinifera.

UFRJ, screened and mounted on entomological pins. Using the stereomicroscope and the Fisher key (2009), the genera were identified. The identification at species level was made based on the key of Vieira et al. (2005), original descriptions of Carrera (1945) and Curran (1934), and by comparison with specimens of the collections of the Museu Nacional (MNRJ) / Universidade Federal do Rio de Janeiro and of the Museu de Zoologia of the Universidade de São Paulo (MZUSP). The specimens were labelled and deposited in the Entomology collection of the Museu Nacional (MNRJ). Photos of the specimens were made using the Leica MZ16 stereomicroscope, using the program Auto Montage Pro by Syncroscopy.

\section{RESULTS AND DISCUSSION}

A total of 682 specimens of Asilidae distributed in 31 genera and 51 species were collected. In the REBIO 527 specimens of 19 genera and 38 species (14 determined and 24 undetermined) were found, whereas in the EEEG 155 specimens of 12 genera and 19 species (6 determined and 13 undetermined) were found.

In REBIO, the following species were identified: Amblyonychus trichonotus (Wiedmann 1828) (two specimens), Andrenosoma rufipennis (Wiedmann 1828) (one specimen), Aphestia nigra (Bigot 1878) (six), Aphestia annulipes (Macquart 1838)(three), Blepharepium cajannense coarctatum (Perty 1833) (five), Eichoichemus pyrrhomystax (Wiedmann 1828) (one), Glaphyropyga pollinifera (Carrera 1945) (19), Lecania leucopyga (Wiedmann 1828) (30) (Fig. 4), Lampria aurifex (Osten Saken 1887) (one), Leptogaster tropica (Curran 1934) (268) (Fig. 5), Leptogaster distincta (Schiner 1867) (one), Mallophora calida (Fabricius 1787) (11), Ommatius spatulatus (Curran 1928) (14), Plesioma caminarium (Wiedmann 1828) (two) e Senobasis gyrophora (Schiner 1968) (three).

In the Buracão track the highest number of specimens $(n=245)$ was captured, followed by Três Pontes $(\mathrm{n}=216)$ and Interpretativa $(\mathrm{n}=66)$. In all of them, Leptogaster Meigen, 1803 was the most abundant genus, with 320 individuals, which is equivalent to $60.72 \%$ of the total collected in REBIO. Of this amount, 199 individuals were found on the Buracão trail, 104 on the Três Pontes trail and 17 on the Interpretativa track. The smaller abundance of Asilidae in the Interpretiva trail may be related to the fact that this is the least extensive trail of REBIO and, therefore, with less supply of microhabitats and resources. In addition, this trail is physically structured to be used in environmental education, and is therefore more visited than the other trails, which results in a greater influx of people, and probably more disturbance. The greater 
abundance of Asilidae in the Buracão and Três Pontes trails may be related to its greater extension and probably greater offer of microhabitats and resources. Buracão is the broadest of the three and the one closest to the highway, possibly having the most edge effect, which may explain the greater number of specimens obtained there (Denys and Tscharntke 2002).

In the EEEG, the following species were identified: Amblyonychus trichonotus) (four specimens), Blepharepium cajannense coarctatum (15) (Fig. 6), Glaphyropyga pollinifera (47) (Fig. 7), Lecania leucopyga (Wiedmann 1828) (eight), Ommatius spatulatus (three) and Ommatius orenoquensis (Bigot 1876) (one).

The Colégio Agrícola trail presented the greatest number of specimens, with 61 individuals, followed by the Marcelo Trindade trail, with 58, the Charco area, with 18, the Abelha trail with 12 and the Vera trail with 6 . The genus that stood out in most of them was Glaphyropyga Schiner, 1866, which presented 15 specimens on the Marcelo Trindade trail, 10 on the Abelha trail and 6 on the Vera trail. In the Colégio Agricola trail and Charco area, the most abundant genus was Leptogaster, with 29 and 12 individuals found in these areas, respectively. The genus Leptogaster was still the most abundant in total numbers, with 54 specimens collected, which represents $34.84 \%$ of the total.

The abundance of these dipterans was clearly higher in the REBIO than in the EEEG, with $77.27 \%$ of the total. Considering that the total area of these two parks and the sample effort were similar, this result may indicate a greater adaptability of the Asilidae to dense ombrophilous forest than to semi-deciduous forest. The former is characterized as more humid environment (without drought period), with perennial vegetation and, therefore, vegetation cover (as in REBIO), while the latter is characterized by presenting a season with intense summer rains, followed by a dry season, where leaf loss occurs (as in EEEG) (IBGE 1992). It is important to add that a large fire hit EEEG in November 2013, which may have also influenced the low abundance of Asilidae.

The REBIO and the EEEG have in commom only 10 genera (Amblyonychus Hermann 1921, Aphestia Schiner 1866, Atomosia Macquart 1838, Blepharepium Rondani 1848, Eicherax Bigot 1857, Eraxasilus Carrera 1959, Glaphyropyga Schiner 1866, Lecania Macquart 1838, Ommatius Wiedmann 1821, Leptogaster Meigen 1803) and six species: Amblyonychus trichonotus (Wiedmann 1828), Atomosia sp.1, Blepharepium cajannense coarctatum (Perty 1833), Glaphyropyga pollinifera (Carrera 1945), Lecania leucopyga (Wiedmann 1828) and Ommatius spatulatus (Curran 1928). The occurrence of these species in both phytophysiognomies with distinct characteristics suggests their good plasticity. These results exemplify the particularities of the local fauna and reinforce the importance of these two areas in maintaining the richness of Asilidae species.

Nine genera and 32 species occurred exclusively in the REBIO, and 2 genera and 13 species were unique to the EEEG. Leptogaster was the most abundant genus in both localities. L. tropica with 268 individuals was the most abundant species in the REBIO and Leptogaster sp. 6, with 54 specimens, the most abundant species in the EEEG.

Applying the Sorensen similarity index (SOi $=2 \mathrm{c} / \mathrm{a}+\mathrm{b}$ ), where " $\mathrm{a}$ " is the number of species occurring in locality 1 , "b" is the number of species occurring in locality 2 and "c" is the number of species in common between the two localities, we obtained the value of 0.21 that indicates the low similarity between the studied physiognomies.

Leptogaster was the most abundant genus in the present study. L. tropica (Curran 1934) with 268 individuals in REBIO and Leptogaster sp.6, with 54 specimens in EEEG were the most abundant species in each locality. One possible explanation would be the smaller size of these two species that 
allows them to occupy and protect themselves in a larger number of microhabitats, due to the use of smaller spaces, unsuitable for larger species.

Applying the Shannon diversity index $H=-\sum \frac{n i}{N} \ln \frac{n i}{N}$, where "ni" is the number of specimens of the species " $\mathrm{i}$ " in the community and " $\mathrm{N}$ " is the total number of specimens in the community, we obtained the value of 2.21 for the REBIO and 1.93 for the EEEG, indicating that the former has a greater diversity of species than the latter.

Concerning the seasonality, we observed that the greatest abundance of most species and genera of the REBIO occurred during the warmest and wettest months (in spring and summer). There was a single exception, Eicherax sp., with more individuals collected in autumn and winter. In the EEEG, the same pattern was observed, except for the genera Aphestia and Cyrtophrys, more abundant in the driest months (in autumn and winter), as seen in Table I. Considering the low number of specimens of both genera (one and four, respectively), we cannot consider that this represents a seasonal pattern for these genera in the EEEG. As expected, the largest quantity of specimens in the two fragments was found in the hot and humid periods, more favorable to their development (Forattini 1962).

TABLE I

Abundance of Asilidae (Diptera) species in the Reserva Biológica União (REBIO) and the Estação Ecológica Estadual de Guaxindiba (EEEG) in each season, during the period of January, 2013 to March, 2014.

\begin{tabular}{|c|c|c|c|c|}
\hline \multirow{3}{*}{ Asilidae species } & \multicolumn{4}{|c|}{ Number of specimens } \\
\hline & \multicolumn{2}{|c|}{ spring/summer } & \multicolumn{2}{|c|}{ autumn/winter } \\
\hline & REBIO & EEEG & REBIO & EEEG \\
\hline Amblyonychus trichonotus & 2 & 4 & - & - \\
\hline Aphestia nigra & 6 & - & - & - \\
\hline Aphestia annulipes & 3 & - & - & - \\
\hline Aphestia sp.1 & - & - & - & 1 \\
\hline Atomosia sp.1 & 4 & 4 & - & - \\
\hline Atomosia sp. 2 & - & 2 & - & - \\
\hline Atomosia sp.3 & - & - & 1 & - \\
\hline Blepharepium cajannense coarctatum & 5 & 12 & - & 3 \\
\hline Cyrtophrys sp.1 & - & - & - & 1 \\
\hline Cyrtophrys sp.2 & - & - & - & 1 \\
\hline Cyrtophrys sp.3 & - & - & - & 1 \\
\hline Cyrtophrys sp. 4 & - & - & - & 1 \\
\hline Diogmites sp.1 & 5 & - & - & - \\
\hline Diogmites sp.2 & 1 & - & - & - \\
\hline Diogmites sp.3 & 1 & - & - & - \\
\hline Efferia $\mathrm{sp}$ & - & 1 & - & - \\
\hline Eichoichemus pyrrhomystax & 1 & - & - & - \\
\hline Eichoichemus sp.1 & 1 & - & - & - \\
\hline Eicherax sp.1 & 13 & - & 20 & - \\
\hline Eicherax sp.2 & 1 & - & 5 & - \\
\hline Eicherax sp.3 & 2 & - & - & - \\
\hline Eicherax sp.4 & - & 3 & - & 1 \\
\hline Eraxasilus sp.1 & 20 & - & 2 & - \\
\hline Eraxasilus sp. 2 & - & 2 & - & 2 \\
\hline Eraxasilus sp. 3 & - & - & - & 2 \\
\hline
\end{tabular}


TABLE I (continuation)

\begin{tabular}{|c|c|c|c|c|}
\hline \multirow{3}{*}{ Asilidae species } & \multicolumn{4}{|c|}{ Number of specimens } \\
\hline & \multicolumn{2}{|c|}{ spring/summer } & \multicolumn{2}{|c|}{ autumn/winter } \\
\hline & REBIO & EEEG & REBIO & EEEG \\
\hline Eraxasilus sp.4 & - & - & - & 1 \\
\hline Glaphyropyga pollinifera & 10 & 7 & 9 & 40 \\
\hline Lecania leucopyga & 25 & 7 & 5 & 1 \\
\hline Lecania $\mathrm{sp} .1$ & 6 & - & 2 & - \\
\hline Lecania $\mathrm{sp} .2$ & 11 & - & 3 & - \\
\hline Lecania sp.3 & 1 & - & - & - \\
\hline Lampria aurifex & - & - & 1 & - \\
\hline Lampria sp.1 & - & - & 1 & - \\
\hline Lampria sp.2 & - & - & 1 & - \\
\hline Leptogaster tropica & 233 & - & 35 & - \\
\hline Leptogaster distincta & - & - & 1 & - \\
\hline Leptogaster $\mathrm{sp} .1$ & 1 & - & 1 & - \\
\hline Leptogaster sp. 2 & 12 & - & 2 & - \\
\hline Leptogaster sp.3 & 3 & - & 4 & - \\
\hline Leptogaster sp.4 & 9 & - & 2 & - \\
\hline Leptogaster sp.5 & - & - & 17 & - \\
\hline Leptogaster sp.6 & - & 29 & - & 25 \\
\hline Mallophora calida & 8 & - & 3 & - \\
\hline Ommatius spatulatus & 14 & - & - & 3 \\
\hline Ommatius orenoquensis & - & 1 & - & - \\
\hline Pilica rufipennis & 1 & - & - & - \\
\hline Plesioma fuliginosus & 2 & - & - & - \\
\hline Senobasis gyrophora & 3 & - & - & - \\
\hline Wilcoxius sp. & 3 & - & - & - \\
\hline Zoticus sp.1 & 3 & - & - & - \\
\hline Zoticus sp.2 & 2 & - & - & - \\
\hline
\end{tabular}

In most genera, the difference in sex ratio between males and females was not very significant, which was predictable considering that they are sexually reproduced and without parthenogenesis (Fisher 1930). Tables II and III show this sex ratio in the REBIO and EEEG, respectively, as well as the number of specimens captured per track.

All genera and species recorded in this study represent new occurrences for the REBIO and EEEG. Besides, eight genera (Atomosia, Efferia, Eichoichemus, Eicherax, Eraxasilus, Plesioma, Wilcoxius and Zoticus) and nine species (Amblyonychus Trichonotus, Andrenosoma rufipenis, Aphestia nigra, Lampria aurifex, Leptogaster tropica, L. distincta, Ommatius spatulatus, Plesioma caninarium, Senobasis gyrophora) had their distribution area extended to the state of Rio de Janeiro.

In addition, three taxa are recorded for the first time in Brazil: Leptogaster distincta, Wilcoxius and Zoticus. These data contribute, in this way, to the knowledge of the geographic distribution and richness of the Asilidae in the state of Rio de Janeiro. In Table IV, data on species abundance and richness are presented for each surveyed area.

\section{CONCLUSION}

The REBIO União and EEEG have low similarity of the Asilidae fauna, showing the importance 
TABLE II

Number of males and females of each genus of Asilidae (Diptera) per trail in the Reserva Biológica União (REBIO), state of Rio de Janeiro, during the period of January, 2013 to March, 2014.

\begin{tabular}{cccccc}
\hline Genus & Male & Female & Buracão & Três Pontes & Interpretativa \\
\hline Amblyonychus & 1 & 1 & 2 & - & - \\
Aphestia & 2 & 7 & 5 & 1 & 3 \\
Atomosia & 3 & 2 & - & 1 & 4 \\
Blepharepium & 4 & 1 & - & 4 & 1 \\
Diogmites & 6 & 1 & 3 & 4 & - \\
Eichoichemus & - & 2 & - & 2 & - \\
Eicherax & 31 & 10 & 15 & 25 & 1 \\
Eraxasilus & 15 & 7 & - & 8 & 14 \\
Glaphyropyga & 10 & 9 & 4 & 8 & 7 \\
Lecania & 24 & 29 & 12 & 34 & 7 \\
Lampria & 1 & 2 & - & 3 & - \\
* Leptogaster & 149 & 160 & 193 & 99 & - \\
Mallophora & 7 & 4 & - & 11 & 6 \\
Ommatius & 7 & 7 & 4 & 4 & - \\
Pilica & - & 1 & - & 1 & - \\
Plesioma & - & 2 & - & 2 & 1 \\
Senobasis & 2 & 1 & - & 2 & 3 \\
Wilcoxius & 2 & 1 & - & - & 2 \\
Zoticus & 1 & 4 & & & \\
\hline
\end{tabular}

* 10 specimens were too damaged to have the sex identified.

TABLE III

Number of males and females of each genus of Asilidae (Diptera) per trail in the Estação Ecológica Estadual de Guaxindiba (EEEG), state of Rio de Janeiro, during the period of January, 2013 to March, 2014.

\begin{tabular}{cccccccc}
\hline Genus & Males & Females & Colégio A. & Marcelo T. & Vera & Abelha & Charco \\
\hline Amblyonychus & 3 & 1 & 3 & 1 & - & - & - \\
Aphestia & - & 1 & - & 1 & - & - & - \\
Atomosia & 5 & 1 & 6 & - & - & - & - \\
Blepharepium & 12 & 3 & - & 14 & - & 1 & - \\
Cyrtophrys & 2 & 2 & 1 & 1 & - & - & 2 \\
Efferia & 1 & - & 1 & - & - & - & - \\
Eicherax & 2 & 2 & - & 4 & - & - & - \\
Eraxasilus & 3 & 4 & & 4 & 3 & - & - \\
Glaphyropyga & 18 & 29 & 13 & 15 & 6 & 10 & 3 \\
Lecania & 5 & 3 & 4 & 4 & - & - & - \\
Leptogaster & 29 & 25 & 29 & 12 & - & 1 & 12 \\
Ommatius & 2 & 2 & - & 3 & - & - & 1 \\
\hline
\end{tabular}


TABLE IV

Species of Asilidae (Diptera) and their abundance in the Reserva Biológica União (REBIO) and Estação Ecológica Estadual de Guaxindiba (EEEG), state of Rio de Janeiro, during the period of January, 2013 to March, 2014.

\begin{tabular}{|c|c|c|c|}
\hline Species & $\mathrm{n}^{\circ} \mathrm{REBIO}$ & $\mathrm{n}^{\circ} \mathrm{EEEG}$ & $\mathrm{n}^{\circ}$ Total \\
\hline Amblyonychus trichonotus & 2 & 4 & 6 \\
\hline Aphestia nigra & 6 & - & 6 \\
\hline Aphestia annulipes & 3 & - & 3 \\
\hline Aphestia sp. 1 & - & 1 & 1 \\
\hline Atomosia $\mathrm{sp} .1$ & 4 & 4 & 8 \\
\hline Atomosia sp.2 & - & 2 & 2 \\
\hline Atomosia sp. 3 & 1 & - & 1 \\
\hline Blepharepium cajannense coarctatum & 5 & 15 & 20 \\
\hline Cyrtophrys sp.1 & - & 1 & 1 \\
\hline Cyrtophrys sp.2 & - & 1 & 1 \\
\hline Cyrtophrys sp.3 & - & 1 & 1 \\
\hline Cyrtophrys sp.4 & - & 1 & 1 \\
\hline Diogmites sp.1 & 5 & - & 5 \\
\hline Diogmites sp.2 & 1 & - & 1 \\
\hline Diogmites sp.3 & 1 & - & 1 \\
\hline Efferia sp. & - & 1 & 1 \\
\hline Eichoichemus pyrrhomystax & 1 & - & 1 \\
\hline Eichoichemus sp.1 & 1 & - & 1 \\
\hline Eicherax sp.1 & 29 & - & 29 \\
\hline Eicherax sp.2 & 10 & - & 10 \\
\hline Eicherax sp. 3 & 2 & - & 2 \\
\hline Eicherax sp.4 & - & 4 & 4 \\
\hline Eraxasilus sp. 1 & 22 & - & 22 \\
\hline Eraxasilus $\mathrm{sp} .2$ & - & 4 & 4 \\
\hline Eraxasilus sp. 3 & - & 2 & 2 \\
\hline Eraxasilus sp.4 & - & 1 & 1 \\
\hline Glaphyropyga pollinifera & 19 & 47 & 66 \\
\hline Lecania leucopyga & 30 & 8 & 38 \\
\hline Lecania sp.1 & 8 & - & 8 \\
\hline Lecania sp. 2 & 14 & - & 14 \\
\hline Lecania sp.3 & 1 & - & 1 \\
\hline Lampria aurifex & 1 & - & 1 \\
\hline Lampria sp.1 & 1 & - & 1 \\
\hline Lampria sp. 2 & 1 & - & 1 \\
\hline Leptogaster tropica & 268 & - & 268 \\
\hline Leptogaster distincta & 1 & - & 1 \\
\hline Leptogaster sp.1 & 2 & - & 2 \\
\hline Leptogaster sp.2 & 14 & - & 14 \\
\hline Leptogaster sp.3 & 7 & - & 7 \\
\hline Leptogaster sp.4 & 11 & - & 11 \\
\hline
\end{tabular}


TABLE IV(continuation)

\begin{tabular}{cccc}
\hline Species & $\mathrm{n}^{\circ}$ REBIO & $\mathrm{n}^{\circ}$ EEEG & $\mathrm{n}^{\circ}$ Total \\
\hline Leptogaster sp. 5 & 17 & - & 17 \\
Leptogaster sp. 6 & - & 54 & 54 \\
Mallophora calida & 11 & - & 11 \\
Ommatius spatulatus & 14 & 3 & 17 \\
Ommatius orenoquensis & - & 1 & 1 \\
Pilica rufipennis & 1 & - & 1 \\
Plesioma fuliginosus & 2 & - & 2 \\
Senobasis gyrophora & 3 & - & 3 \\
Wilcoxius sp. & 3 & - & 3 \\
Zoticus sp. 1 & 3 & - & 3 \\
Zoticus sp. 2 & 2 & & 2 \\
\hline
\end{tabular}

of preserving the different physiognomies of the Atlantic Forest as a way of preserving the richness of these Diptera.

The new records of genera and species increase the knowledge of the richness and distribution of this family in the state of Rio de Janeiro. Such information is essential for the understanding of distribution patterns, as well as the identification of areas of endemism and species richness, and are essential for wildlife conservation.

\section{ACKNOWLEDGMENTS}

We thank the Instituto Estadual do Ambiente (INEA) for collection authorization number 37716-1.

\section{REFERENCES}

ARTIGAS JN AND VIEIRA R. 2014. New genus and species of Neotropical robber flies (Diptera, Asilidae, Asilinae). Zootaxa 3774(3): 282-288.

CARRERA M. 1945. Estudo sobre os gêneros Glaphyropyga e Senoproposis com descrição de novo gênero e novas espécies. Paps Avs, Dept. Zool. São Paulo 5(19): 175-192.

CARVALHO JLN, AVANZI JC, SILVA LMN, MELLO CR DE AND CERRI CEP. 2010. Potencial de sequestro de carbono em diferentes biomas do Brasil. Rev Bras Ciênc Solo 34: 277-289.

CURRAN CH. 1934. The Diptera of Kartabo, Bartica District, British Guiana. Bull Am Mus Nat Hist Vol. LXVI, Article III: 329-330.
DENYS C AND TSCHARNTKE T. 2002. Plant-insect communities and predatorprey ratios in field margin strips, adjacent crop fields, and fallows. Oecologia 130(2): 315-324.

FISHER EM. 2009. Asilidae (Robber flies, assassin flies, moscas cazadoras, moscas ladronas), p. 585-632. In: Brown BV et al. (Eds), Manual of Central American Diptera: volume 1. NRC Research Press, Ottawa, Ontario, Canada, 714 p.

FISHER RA. 1930. The Genetical Theory of Natural Selection. Clerendon Press, Oxford, p. 24-27.

FORATTINI OP. 1962. Entomologia médica. Faculdade de Higiene e Saúde Pública, São Paulo, p. 662.

GUIMARÃES RR, JÚNIOR RRG, VIEIRA R, GUIMARÃES RR, DOS SANTOS SEPPA G AND DE CARVALHO RW. 2016. The robber flies (Diptera, Asilidae) from Marambaia Island, Rio de Janeiro, Brazil. Check List 12(1): 1829.

HULL FM. 1962. Robber flies of the world. Bull USNM 224: 1-907.

IBGE. 1992. Manual técnico da vegetação brasileira. $1^{a}$ ed., Rio de Janeiro: IBGE 92 p. (Manuais técnicos em geociências, n.1). Disponível em http://biblioteca.ibge.gov.br/index. $\mathrm{php} /$ bibliotecacatalogo?view=detalhes\&id=223267.

INEA - INSTITUTO ESTADUAL DO AMBIENTE. 2000. Estação Ecológica Estadual de Guaxindiba. 2000. Encarte de divulgação, 2 p. Disponível em <http://www.inea. rj.gov.br/cs/groups/public/.../zwew/.../inea0026736.pdf, acesso em 21/fev/2017.

JOERN A AND RUDD NT. 1982. Impact of predation by the robber fly Proctacanthus milbertii (Diptera: Asilidae) on grasshopper (Orthoptera: Acrididae) populations. Oecologia 55: 42-46.

MMA. 2008. ICMBIO, Instituto Chico Mendes. Plano de Manejo, Reserva Biológica União, encarte 1 - contextualização da unidade de conservação, p.127. Disponível em <http://www.icmbio.gov. br/portal/biodiversidade/unidadesde-conservacao/ 
biomasbrasileiros/mata-atlantica/unidades-deconservacaomata-atlantica/2144-rebio-uniao.html> acesso em 9/ fev/2017.

MOREIRA-JUNIOR D AND MAIA VC. 2016. Primeiro registro do gênero Leptogaster Meigen (Diptera: Asilidae) no Estado do Rio de Janeiro e sua abundância na Reserva Biológica da União (RJ, Brasil). In: Da-Silva ER, Passos MIS, Aguiar VM, Lessa CSS and Coelho LBN (Eds), Anais do III Simpósio de Entomologia do Rio de Janeiro. Universidade Federal do Estado do Rio de Janeiro (UNIRIO), Rio de Janeiro, p. 70-76.

MORELLATO LPC AND HADDAD CFB. 2000. Introduction: The Brazilian Atlantic Forest 1. Biotropica 32(4): 786-792.
PAPE T, BLAGODEROV V AND MOSTOVSKI MB. 2011. Order Diptera Linnaeus, 1758, In: Zhang ZQ (Ed), Animal biodiversity: An outline of higher level classification and survey of taxonomic richness. Zootaxa, p. 222-229. https:// doi.org/10.11646/zootaxa.3703.1.6.

SHUROVNEKOV BG. 1962. Field entomophagous predators (Coleoptera, Carabidae, and Diptera, Asilidae) and factors determining their efficiency. Entomol Rev 41: 476-485.

VIEIRA R, CASTRO I AND BRAVO F. 2005. A new species of Ommatius Wiedemann (Diptera: Asilidae) from Brazil. Zootaxa 1017: 19-24.

VIEIRA RM AND RAFAEL JA. 2014. Longivena, a new robber-fly genus from Brazil (Diptera, Asilidae, Asilinae). Zookeys 443: 119-138. 